\title{
The Use of Cartometric and Participatory Methods for Evaluating Regional Boundaries in Kaligesing Sub-district , Purworejo, Indonesia
}

\author{
Sudaryatno $^{\text {a }}$, Bagus Wiratmoko ${ }^{\mathrm{b}}$, Ramadhani Yuda $^{\mathrm{c}}$ \\ ${ }^{a}$ Lector Departemen Sains Informasi Geografis Geography Faculty of Universitas Gadjah Mada, \\ Sudaryatno@ugm.ac.id. \\ ${ }^{b \& c}$ Departemen Sains Informasi Geografis Geography Faculty of Universitas Gadjah Mada. \\ Baguswiratmoko@mail.ugm.ac.id
}

\begin{abstract}
Related to the implementation of regional autonomy (UU No. 32 Tahun 2004), the determination of regional boundaries is one of the main factors in the implementation of regional government functions. Regional boundaries that are not clear at the border can trigger conflicts that can obstruct the development of society. The conflict is not only limited to social conflicts, but also conflicts in the administrative affairs of population and local government. If it is not immediately resolved, it can reduce the level of government service to the community. Remote sensing image technology and cartography become one of the options that can help facilitate in terms of cost efficiency and time effectiveness for mapping regional boundaries. This study utilizes remote sensing image to map regional boundaries using the cartometric and participatory methods. By drawing boundaries on work maps and measuring the position of points, distances and area coverage by using basic maps and other maps as a complement and also with verification from the local government as the participator to withdraw the limit. With the cartometric and participatory method and the help of remote sensing imagery in this study that can minimize field activities with the terms of the image used has a higher resolution than the base map used. The results of this study are the map Kaligesing sub-district boundary of Purworejo District, Central Java, that that has been verified. This verified map will be used for identifying the extend differences of this area, by comparing it to the Administration Map provided by the national government. Except that the result can be use to another research such as to boundary unit of disaster, or to make cadastral map in village level.
\end{abstract}

Keywords: : Bondaries Mapping, Cartometric, Participatory, Regional Boundaries

\section{Introduction}

In Indonesia regional boundaries are a national issue. The importance of regional boundaries is to regulate the autonomous rights of each region in accordance to UU No. 23 of 2004. By defining clear boundaries it will reduce the risk of polemics and boundary disputes between two regions that have potential natural resources in the border area.

Regional boundaries are a series of coordinate points which are the boundaries of government administrative areas located on the surface of the earth, can be in the form of natural boundaries and artificial elements (Permendagri, No. 76 of 2012). Determination of regional boundaries can be done by means of cartometrics or participatory or it could be by combining the two methods. Determination of boundaries must be precise because it is closely related to the making of cadastral maps. (Basiouka, 2014)

The cartometric method is the drawing of a boundary on a map / image based on the cartometric methods set by the government (Kemendagri,2016). Participatory methods are boundary withdrawals with the help of the active role of the community and local instruments as information providers and mapping actors. Therefore regulations need to be made to maintain the quality of the data produced. (Mustofa, at all. 2018)

Regional boundary mapping activities use the cartometric and participatory methods using media in the form of remote sensing images. Remote sensing imagery has a role as a guide or helper in drawing limits. With the appearance of remote sensing images it will make it easier for the community and also the regional apparatus to determine the reference points that become the boundary between the two regions. The superiority of remote sensing imagery in boundary mapping is able to nullify field activities that can be used as a reference for areas that are difficult to reach and to estimate the cost and time of activities.

The purpose of this study is to apply the method of boundary withdrawal in a cartometric and participatory manner using the help of remote sensing imagery which would be used to evaluate the boundaries RBI maps that created by the govermnet. In addition, it also wants to provide education to the regional governments that participate in activities, how to determine boundaries that are in accordance with state regulations and are able to be accepted by the two bordering regions. So later the regional government especially the sub-district level is able to apply it to the level of government below it, which is in the level of village. Regional boundary maps of 
community participatory results can also be used as references in cadastral mapping activities and disaster mapping. This can be linked to disaster mitigation activities and potential disaster mapping, with the zoning system, or it can be use as boundary unit to make disaster map such as landslide or flood in village level (Sudaryatno, 2017)

\subsection{Location of Study}

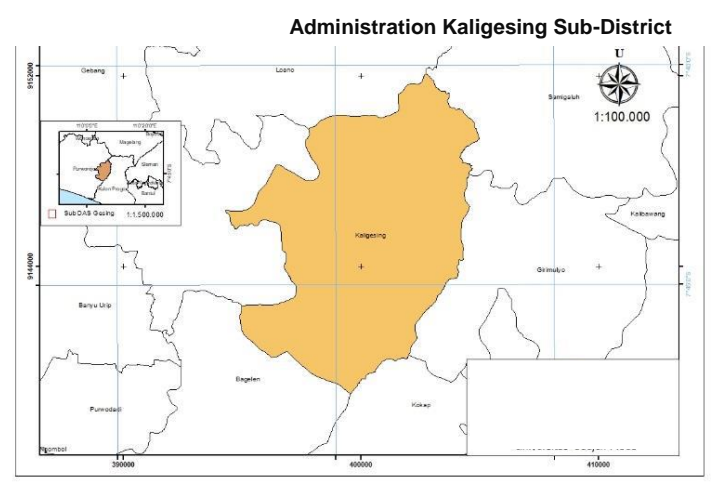

Picture 1. Kaligesing Sub District

Kaligesing District, Purworejo Regency, Central Java Province. Consisting of 21 villages. The North is bordered by Samigaluh sub-district, east of Girimulyo sub-district, south of Bagelen sub-district, and west of Purworejo city.

\section{Research Method}

\subsection{Research Data}

1. Peta RBI scale $1: 25.000$.

2. High-resolution imagery

3. Support maps from related villages / sub-districts (boundary maps of each village).

4. DEM as a helper through topographic elements.

\subsection{Research Tools}

1. Laptop to manage high-resolution imagery data

2. Colored OHP markers, to draw boundaries on maps / images

\subsection{Research Phase}

\subsubsection{Collecting Data Phase}

a. Topographic Map of Indonesia

This data can be obtained by downloading on the website of the Geospatial Information Agency (BIG). The type of data needed from the RBI map (Rupabumi) is the administrative boundary up to the village level in Purworejo District on a scale of 1: 25,000, road data, and river flow data. Administrative boundary data will be used as the beginning guideline in withdrawing regional boundaries, because the data is output data that comes from the government, while the road and river data make supporting data in identifying objects in the field.

\section{b. High Resolution Image Data}

Image data has a function as the main guideline in the process of recognizing objects on the surface of the earth. People will more easily recognize objects if they interpret them based on images that represent the original conditions on the surface of the earth. The image data used is ESRI Basemap data because of its geometric factors that are in accordance with Indonesian topographical maps.

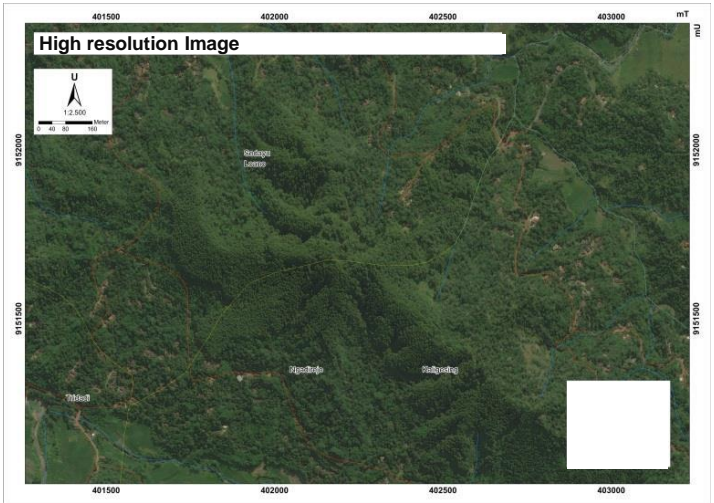

Picture 2. High Resolution Image of ESRI

\section{c. Image of DEM}

DEM imagery is used because it is able to present topographical information on the surface of the earth. The DEM data used is the SRTM DEM (Shuttle Radar Topography Mission) which can be downloaded for free. DEM imagery is used to visualize the condition of the study area in $3 \mathrm{D}$ using hillshade modeling. The model will be made as one of the guidelines for withdrawal because the majority of regions have mountainous terrain and terrain so it will be very helpful in identifying boundaries in the igir or valley area.

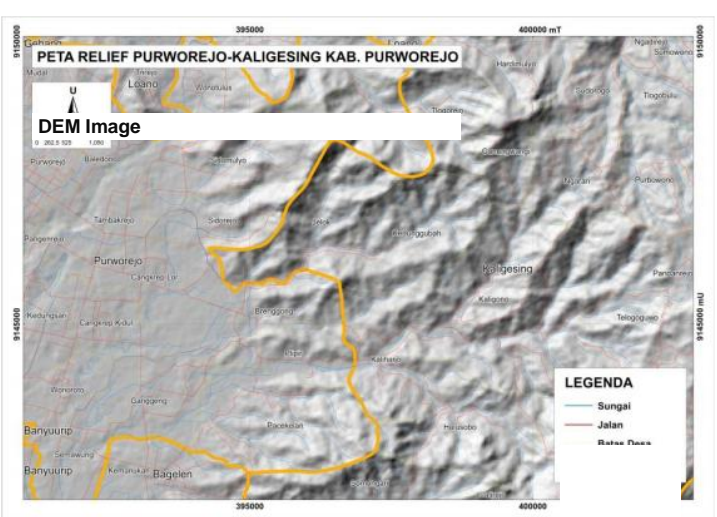

Picture 3. DEM Image

\subsubsection{Field Research Phase}

a. Focus Group Discussion (FGD)

The FGD focuses on the administrative boundaries of the Kaligesing sub-district. In practice, the parties involved or areas directly adjacent to the Kaligesing sub-district are needed in Purworejo Regency. Boundary determination is done at the sub-district level, but the participants are at the village level 
because to get more accurate and detailed information regarding regional boundaries.

The purpose of the FGD is to draw boundaries together on a map / image sheet, from the Kaligesing sub-district with adjacent areas. Line drawings are carried out in a cartometric manner with a participatory determination between adjacent parties.

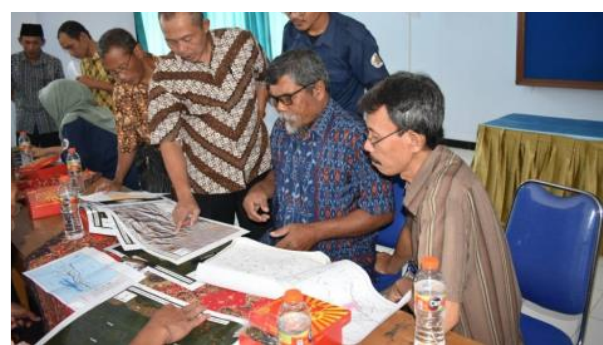

Picture 4. FGD Session

\section{b. FGD Data Processing}

This phase is to convert FGD data in the form of images on a map / print image into digital form. The next one will be analyzed the results of the boundary mapping to evaluate the boundaries of the RBI map.

Data from the FGD are printed maps with signs in the form of lines and dots which are boundary boundaries between two regions. This limit is in the form of natural boundaries such as igirs, rivers and gutters, as well as artificial boundaries such as archways, monuments or roads.

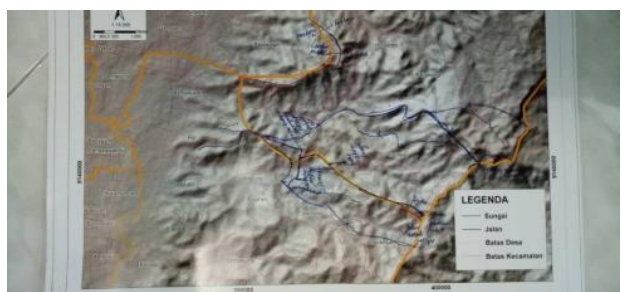

Picture 5. FGD map result

2.3.3 Flow diagram research

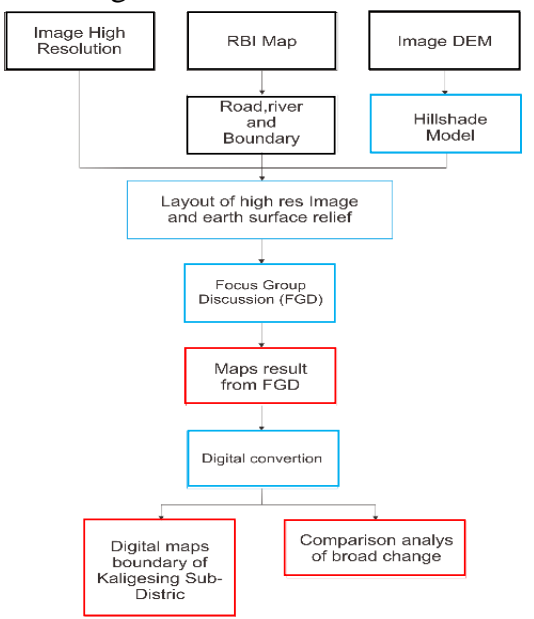

Diagram 1. Flow diagram

\section{Results of Analysis and Discussion}

Boundary mapping uses the cartometric and participatory methods. The most important phase is the FGD (Focus Group Discussion), because at this phase the boundary lines are drawn together between the two adjacent parties. So that the resulting limit is the limit of agreement between the two parties which are expected to be able to minimize boundary disputes.

There are 4 sub-districts participating in this research, that is Kaligesing, Purworejo, Loano, and Bagelen, but the boundary measurements are concentrated at the Kaligesing sub-district boundary. Of the 4 sub-districts followed by 20 villages, which are divided into 10 Kaligesing sub-villages located on the border, 4 villages in Purworejo sub-district, 3 subdistricts of Bagelen sub-district, and 3 sub-districts in Loano sub-district.

The purpose of this study is to evaluate the boundaries that already exist in this case from a 1 : 25,000 scale Indonesian topographic map made by the Country. Evaluation is done through FGD. Technical FGDs are two villages bordering an image map that covers their area. In the map there is also administrative boundary information from the RBI, road data and river flow data that can be used as assistance in determining boundaries. Next they will draw a line together to get the line agreed upon by both parties.

\subsection{Analysis of Evaluation Result}

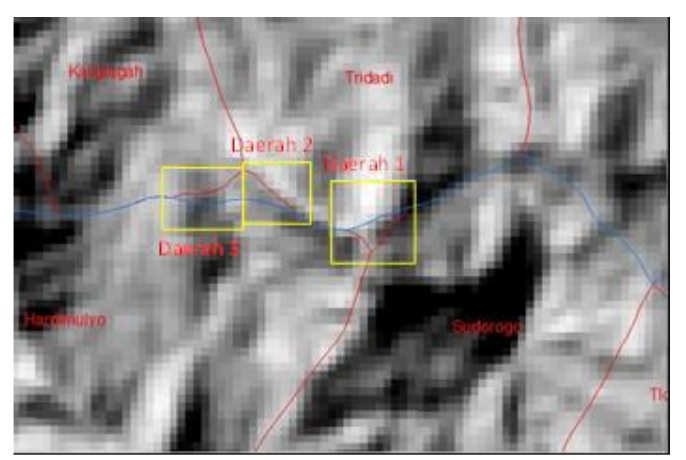

Picture 6. Kaligesing - Loano Sub district

(the red color of the cartometric and participatory boundary, the blue color is RBI boundary)

The changes of boundaries occur at 3 points. The boundary involved 3 villages, 2 villages Loano, 1 village Kaligesing. The location of the boundary is in the forest in the hills, so there is no agreement on boundaries between the 3 villages. Therefore according to the boundary cartometric rules that cross the mountains and do not have a peg agreement between the adjacent parties, the boundary follows the mountain igir (red ). 


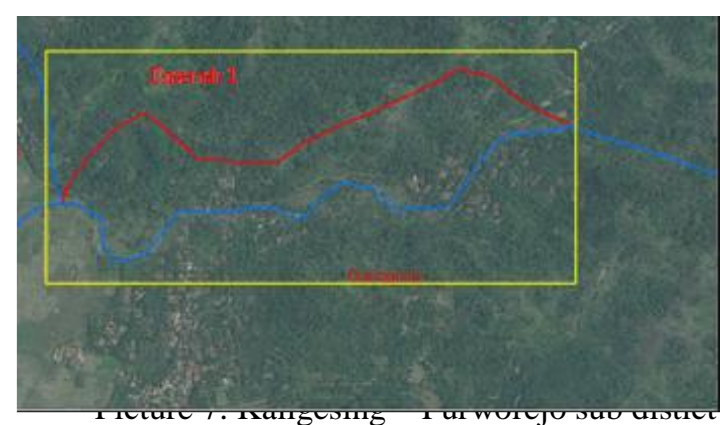

Boundary changes occur between two villages. Based on the RBI boundary segment (in blue) the boundary follows the arterial road flow, but the results of the participatory village apparatus concerned produce a boundary on the slope above the countryside (red). Because villages that were previously separated by two borders turned out to be the same village

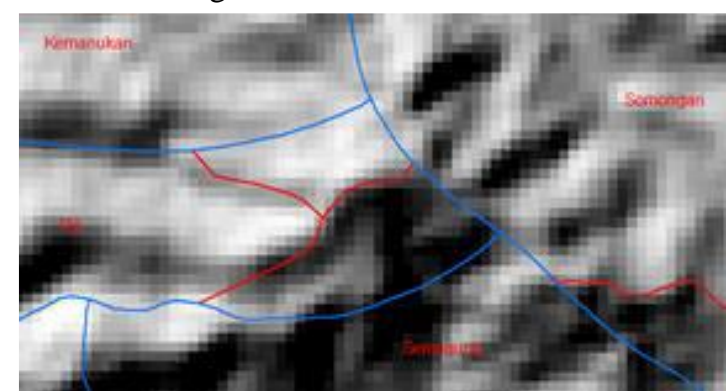

Picuter 8. Kaligesing - Bagelen Sub district

The changes of boundary here is if according to the Topographical map there are 3 villages bordering the Kaligesing sub-district (in blue). But after participatory mapping there were only two villages bordering the Kaligesing sub-district. So that the boundary line is drawn participatively in accordance with the agreement of the 3 villages following the rules of cartometrics, namely being in the igir hill because there is no agreement on boundaries from the village concerned.

\subsection{Analysis of the results of the comparison area}

Based on the analysis in each village area, there were changes area in several villages. This change in area is very important because it affects the detailed information about the geographical conditions of Kaligesing Sub District. Based on this table, it can be observed that the area has increased or decreased from several participating villages.

\begin{tabular}{|l|l|l|}
\hline Kaligesing & Loano & $\begin{array}{l}\text { Increase area } \\
\text { (Ha) }\end{array}$ \\
\hline Hardimulyo & $\begin{array}{l}\text { Kaliglagah, } \\
\text { Tridadi, Rimun }\end{array}$ & 14.783073 \\
\hline Tlogorejo & Rimun & 11.608311 \\
\hline Total & Purworejo & $\begin{array}{l}\text { Increase area } \\
\text { (Ha) }\end{array}$ \\
\hline Kaligesing & Sudimoro & 1.680242 \\
\hline Kedunggubah & $\begin{array}{l}\text { Sidomulyo, } \\
\text { Sidorejo }\end{array}$ & 9.567717 \\
\hline Jelok & Plipir & 0.635291 \\
\hline Kaliharjo & Pacekelan & 0.423827 \\
\hline Hulusobo & & 12.307077 \\
\hline Total & Bagelen & $\begin{array}{l}\text { Increase area } \\
\text { (Ha) }\end{array}$ \\
\hline Kaligesing & Semono & 7.745649 \\
\hline Somongari & & 7.745649 \\
\hline Total & & $\mathbf{4 6 . 4 4 4 1 1 0}$ \\
\hline \multicolumn{2}{|l|}{ Total area (ha) } &
\end{tabular}

Table 1. Increase Area Table

\begin{tabular}{|c|c|c|}
\hline Kaligesing & Loano & $\begin{array}{l}\text { Decrease area } \\
(\mathrm{Ha})\end{array}$ \\
\hline Sudorogo & Tridadi & 0.629972 \\
\hline Hardimulyo & Tridadi & 0.665806 \\
\hline \multicolumn{2}{|l|}{ Total } & 1.295778 \\
\hline Kaligesing & Purworejo & $\begin{array}{l}\text { Decrease area } \\
\text { (Ha) }\end{array}$ \\
\hline Tlogorejo & Donorati & 2.570168 \\
\hline Jelok & $\begin{array}{l}\text { Sidomulyo, } \\
\text { Sidorejo, } \\
\text { Brenggong }\end{array}$ & 31.353378 \\
\hline Kaliharjo & Plipir & 5.618291 \\
\hline Hulusobo & Pacekelan & 0.922025 \\
\hline \multicolumn{2}{|l|}{ Total } & 40.463862 \\
\hline Kaligesing & Bagelen & $\begin{array}{l}\text { Decrease area } \\
\text { (Ha) }\end{array}$ \\
\hline Somongari & $\begin{array}{l}\text { Semagung, } \\
\text { Semono }\end{array}$ & 20.396292 \\
\hline Jatirejo & $\begin{array}{l}\text { Semono, } \\
\text { Durensari }\end{array}$ & 6.900625 \\
\hline \multicolumn{2}{|l|}{ Total } & 27.296917 \\
\hline \multicolumn{2}{|l|}{ Total area } & 69.056557 \\
\hline
\end{tabular}

Table 2. Decrease Area table

Based on the results of analysis in each village area, there have been changes in area in several villages. This change in area is very important because it affects the detailed information about the geographical conditions of Kaligesing District. Based on this table, it can be observed that the area has increased or decreased from several participating villages. 


\section{Conclusion}

1. Mapping regional boundaries using the cartometric and participatory methods are quite effective, especially for areas with natural nature such as forests, mountains, and rivers.

2. 2. The remote sensing image has a very important role because it is the main guideline in observing objects in determining the point or boundary line, especially for forest areas in the mountains whose boundaries can be determined by the igir.

3. Based on the results of the evaluation of the boundaries of the RBI map, it cant yet be fully referenced in village development planning, because differences with the actual boundaries in the field are quite significant, both in terms of area and line and different boundary points.

\section{Acknowledgements}

Our sincere thank to colleague which helped to completing this research, foremost Ministry of Research, Technology and Education of the Republic of Indonesia, and Geography Faculty for funding this research.

\section{References}

Basiouka, S., and Potsiou, C., 2014. The Volunteered Geographic Information in Cadastre : Perspective and Citizens' Motivations over Potential Participation in Mapping. GeoJournal, Vol. 79(3), 343-355. http:/doi.org/10.1007/s10708-013-9497-7

Fatkhawati, A. F. and Rahardjo, N. 2017. Determination of the Regional Boundary In Kartometrik Using Spot Image Between Malinau District (North Borneo) with East Kutai and Berau district (East Kalimantan). Indonesian Earth Journal. Vol. 6.

Hidayat. 2005. Panduan Pemetaan Partisipatif No. 2 - Mengenalkan Pemetaan Partisipatif, Garis

Pergerakan, Bandung.

Kemendagri. 2016. Peraturan Menteri Dalam Negeri No. 45 tahun 2016, Penetapan dan Penagasan Batas Desa. Ministry of Home Affairs Indonesia, Jakarta.

Mustofa. C. Fahmi, et all. 2018. Evaluation of Participatory Mapping to Develop Parcel-Based Maps for Village-Based Land Registration Purpose. International Journal of Geoinformatics, Vol 14(2), DOI: 10.5281/Zenodo.1409285

Permendagri Nomor 76 tahun 2012, Tentang Pedoman Penegasan Batas Daerah. Ministry of Home Affairs Indonesia, Jakarta.

Sudaryatno et al. 2017. Participatory Mapping for Flood Disaster Zoning based on World View-2 Data in Long Beluah, North Kalimantan Province. $5^{\text {th }}$ Geoinformation Sciences Symposium. Earth Environ Sci 98012011. DOI:10.1088/1755-1315/98/1/012011.

Sutanto. 1992. Penginderaan Jauh Jilid I. Gadjah Mada University Press, Yogyakarta. 